DOI https://doi.org/10.36059/978-966-397-155-1/26-43

\title{
TRAINING OF PUBLIC HEALTH PROFESSIONALS IN UKRAINE: EXPERIENCE AND PROBLEMS
}

\author{
Bilak-Lukianchuk V. Yo.
}

\section{INTRODUCTION}

Health of the population is the most important resource in any country. In nowadays reality, all national health systems are prioritizing and developing public health services. One of the main tasks of reforming the health care system, implementing and improving public health services is to prepare a new generation of public health professionals. Formation of Ukraine as a democratic, legal, social state with a socially-oriented economy, its European and Euro-Atlantic integration envisage creation and development of a highly-qualified structure of health care professionals both in medical institutions and in governmental agencies - practitioners and scientists, civil servants and local government officials.

Human resources ensure the efficiency and quality of the provision of appropriate medical and management services. Human resources is working capacity of the company, the ability of staff to generate ideas, create new products, its educational, qualification level, psychophysiological characteristics and motivation.

Stability of system potential and human resources development are among the priorities of new European policy «Health 2020». All 53 Member States of European region of WHO have decided to create a new common policy framework - «Health 2020». Its general goal is «to significantly improve health and promote well-being of the population, reduce health inequalities, strengthen public health system and ensure that there are universal, socially just, sustainable and high-quality humancentered health care systems». «Health 2020» takes into account the diversity of countries in the region. Policy framework appeals to diverse audiences - both within and outside governmental agencies - inspiring them and offering optimal ways to address complex health care challenges in the 21 st century. Health care efficiency and economic efficiency are interrelated.

1 Zdorov'e - 2020. Osnovy evropeyskoy politiki i strategiya dlya XXI veka (2013) [Health -2020 . European policy framework and strategy for the 21 st century]. Retrieved from: http://www.euro. who.int/PubRequest?language=Russian 
At the same time, the optimal use of resources in health care sector and, above all, human resources is crucial.

In Ukraine, the health care area is focused on treating diseases rather than preventing them. Most resources are directed at treatment of diseases, and only a small portion are concentrated on preserving health. One of the key tasks of health care reform is to shift from a treatment policy to a policy of preserving and promoting health and preventing diseases.

Public health is a system of scientific, political, economic, medical and social measures aimed at organizing the efforts of society, state-owned and non-governmental institutions, communities and individuals to promote health, prevent diseases, extent active and working age by providing conditions that keep people healthy, as well as promoting a healthy lifestyle. Public health is concerned with threats to health of the population. Public health focuses on improving health and quality of life through the prevention and recovery from diseases and the elimination of factors that affect physical and mental health, by controlling the determinants of health and shaping a healthy lifestyle. Modern public health practice requires the effective work of an interdisciplinary team of specialists.

The aim is to create a system in which each central and local government executive takes into account consequences of his/her decisions for health of the population and prioritizes activities that help people avoid illness and injury and be healthy. Building a public health system in Ukraine is one of the requirements of the Association Agreement between Ukraine and the European Union.

In the European Region of WHO, the definition of public health as «the science and practice of disease prevention, life extension and health promotion through organized, community-based action» proposed by Acheson is used ${ }^{2}$.

\section{International and national prerequisites for training personnel for public health system}

In 2012, the European Regional Bureau of the World Health Organization (WHO) adopted the document «European Action Plan for Strengthening of Public Health Capacities and Services» (EAP), which has become a guide to public health development in European region ${ }^{3}$.

\footnotetext{
${ }^{2}$ Acheson D. (1988) Public health in England: the report of the Committee of Inquiry into the Future Development of the Public Health Function. London, H. M. Stationery Office.

3 Evropeyskiy plan deystviy po ukrepleniyu potentsiala i uslug obshchestvennogo zdravookhraneniya (2012) [European Action Plan for Strengthening of Public Health Capacities and Services]. Copenhagen: WHO Regional Office for Europe, (document EUR/RC62/12).
} 
The objective of the EAP is to support European Member States in improving health, reducing inequality, and ensuring implementation of essential public health operations (EPHOs) and a basic list of affordable, high quality, effective public health services on an individual basis, local and population levels, and strengthening the capacity of the public health system.

The task of EAP is to develop and implement, monitor, evaluate actions on strengthening of public health system potential and services through a broad consultation process involving all WHO Member States and key international partners.

The EAP on strengthening of public health system potential and services across Europe is not just a technical document. It is an action-oriented initiative, and its development and implementation reflects the values and principles secured at «Health 2020», outlining the vision and direction of health policy for sake of health in Europe in the 21st century.

Resolution of WHO Regional Committee for Europe EUR/RC60/R5 outlines major areas of action to address key public health care and health policy challenges in Europe that need to increase political commitment to the development of public health capacities, functions and services, and take concrete steps to invest resources in preventing and promoting human health; to continue actively focus on health systems strengthening (conform and, where appropriate, clarify definitions, concepts, functions and relationships, and develop tools for practical implementation), to review public health care tools for the 21 st century; to conduct critical appraisal of all ongoing activities, especially in setting standards and norms, in order to make best use of the experience and structures existing in the Region; to work closely with partners when solving all of the above tasks.

Both principles of «Health 2020» and EAP call for a commitment to improving health and reducing inequalities through a nationwide and community-wide approach. That is, the task of improving public health involves appropriate mechanisms of strategic management, and the decisionmaking process is based on basic principles of human rights, social justice, partnerships and sustainable development ${ }^{4}$.

The EAP is one of the fundamental components of the policy «Health 2020». Key areas of activity regard to strengthening and further development and supporting potential and services of public health system to

\footnotetext{
${ }^{4}$ Slabkyj Gh.O., Myronjuk I.S., Kachala L.O. (2017) Systema ghromadsjkogho zdorov’ja: bachennja Vsesvitnjoji orghanizaciji okhorony zdorov'ja, Osnovni operatyvni funkciji ghromadsjkogho zdorov'ja ta jikh zmist [Public Health System: World Health Organization Vision, Essential Public Health Functions and Their Meaning]. Ukrajina. Zdorov'ja naciji, no. 3 (44), pp. 24-31.
} 
improve health and reduce inequalities by influencing the social determinants of health. The unifying principle of the public health system is its social character, as well as the fact that it is focused mainly on the health of population in general. The public health system can be seen as a key aspect of the wider health care system and can play an important role in enhancing the efficiency and effectiveness of the functioning of health care system. It is proposed to keep the definition of «health care system» approved in 2008 by Tallinn Charter: «Within the political and institutional boundaries of each country, the health care system is the totality of all public and private organizations, institutions, resource structures which purpose is to improve, preserve or restore the health of people. Health care systems include the provision of both individual and public services, as well as actions to influence the policies and activities of other sectors to give due consideration to social, environmental and economic determinants of health» ${ }^{5}$.

The health care system (managed by the Ministry of Health) plays a central role in the management of public health and the provision of public health services. Thus, public health care is also directly relevant to health care systems, and these systems, in their turn, can only be effective if they have a strong component associated with public health services.

Ten EPHOs are proposed in a form of detailed list to evaluate the potential and services of the public health system and the actions needed to improve them. They are among the most important services in the public health system (EPHOs 1-5), and are relevant to all aspects (EPHOs 6-10) and contribute to the implementation of EPHOs 1-5. The EPHOs are not expected to be considered as 10 separate services. They can be adapted according to different conditions and performed in groups or blocks. For example, EPHOs 1 and 2 mainly relate to analytical information on public health that can be used in the process of problem solving regarding health care and promotion and disease prevention (EPHOs 3-5), while EPHOs 6-10 are intended to facilitate improving service delivery as a whole.

The seventh essential public health operation is to provide the public health area with sufficient number of qualified personnel.

\footnotetext{
${ }^{5}$ Sistemy zdravookhraneniya - zdorov'e - blagosostoyanie: Evropeyskaya ministerskaya konferentsiya VOZ po sistemam zdravookhraneniya (2008) [Health systems - Health Welfare: WHO European Ministerial Conference on Health Systems]. Tallinn, Estonia. Report (2009) Copenhagen: WHO Regional Office for Europe. Retrieved from: http://www.euro.who.intassets/pdf_file/0003/78951/E92150 R.pdf.
} 
WHO has adopted a number of important instruments that should contribute to the development of public health system in the region and in Ukraine directly $^{6}$, .

In Ukraine, the formation of a new public health service is conformed with program international and national documents, first of all with the Sustainable Development Strategy «Ukraine 2020» ${ }^{8}$, approved by the Decree of the President of Ukraine of January 12, 2015, the Association Agreement between Ukraine and the EU, section 22 of which outlines the priority tasks and courses of activity in the field of public health ${ }^{9}$. Institutional formation of the national public health service is conducted in accordance with the Concept for Development of the Public Health System, approved by the Decree of the Cabinet of Ministers of Ukraine of November 30, 2016 № 1002-p. ${ }^{10}$ and Action Plan for the Implementation of the Concept for Development of the Public Health System, approved by the Decree of the Cabinet of Ministers of Ukraine of August 18, 2017 No. 560-p. ${ }^{11}$ The Concept defines the courses, mechanisms and timing of the formation of public health system, with the aim of developing and implementing effective

${ }^{6}$ Komissiya po sotsial'nym determinantam zdorov'ya. Likvidirovat' razryv $\mathrm{v}$ techenie zhizni odnogo pokoleniya. Soblyudenie printsipa spravedlivosti v zdravookhranenii putem vozdeystviya na sotsial'nye determinanty zdorov'ya (2009) [Commission on Social Determinants of Health. Closing the gap in a generation. Health equity through action on the social determinants of health]. Final report of the Commission on the Social Determinants of Health. Geneva, WHO. Retrieved from: http://www.who.int/social_determinants/ thecommissionfnalreport/ru/index.html.

7 Rezolyutsiya WHA62.14 Vsemirnoy assamblei zdravookhraneniya "Umen'shenie nespravedlivosti v otnoshenii zdorov'ya posredstvom vozdeystviya na sotsial'nye determinanty zdorov'ya" (2009) [Resolution WHA62.14 of World Health Assembly «Reducing health inequities through action on the social determinants of health»]. Geneva, WHO. Retrieved from: http://apps.who.int/gb/or/r/r_wha62r1.html..

8 Pro Strateghiju stalogho rozvytku «Ukrajina - 2020», Ukaz Prezydenta Ukrajiny № 5/2015 vid 12.01.2015 [On the Sustainable Development Strategy «Ukraine 2020», Presidential Decree № 5/2015 of 12.01.2015]. Retrieved from: https://zakon.rada.gov.ua/laws/ show/5/2015

${ }^{9}$ Ughoda pro asociaciju mizh Ukrajinoju ta JeS: zmist ta implementacija [EU-Ukraine Association Agreement: content and implementation.]. Retrieved from: https://parlament.org.ua/ upload/docs/final_1.pdf

10 Pro skhvalennja Koncepciji rozvytku systemy ghromadsjkogho zdorov'ja, Rozporjadzhennja Kabinetu Ministriv Ukrajiny №1002-r. vid 30.11.2016 [On approval of the Concept of development of the public health system, Order of the Cabinet of Ministers of Ukraine №1002-p. of 30.11.2016]. Retrieved from: https://zakon.rada.gov.ua/laws/show/10022016-\%D1\%80

${ }^{11}$ Pro zatverdzhennja planu zakhodiv shhodo realizaciji Koncepciji rozvytku systemy ghromadsjkogho zdorov’ja, Rozporjadzhennja Kabinetu Ministriv Ukrajiny № 560-r vid 18.08.2017 [On Approval of the Action Plan for the Implementation of the Concept of Public Health System Development, Order of the Cabinet of Ministers of Ukraine № 560-p of 18 August 2017]. Retrieved from: https://zakon.rada.gov.ua/laws/show/560-2017-\%D1\%80 
public policies to promote health, prevent diseases, extend active and working age and encourage healthy lifestyles through the united efforts of the entire society.

Further work in the country is aimed at providing the public health system with qualified personnel. So, in 2015 the CMU approved the specialty «Public Health» ${ }^{12}$, and subsequently the Ministry of Education and Science of Ukraine approved educational standards for training of bachelors and masters ${ }^{13}$ in the specialty «Public Health».

A significant step in human resourcing of the newly created service was inclusion of the specialty «Public health» into the list of specialties available for the students of higher educational institutions, according to the Decree of the Cabinet of Ministers of Ukraine dated 01.02.2017 No. 53 «On Amendments to the Decree of the Cabinet of Ministers of Ukraine dated April 29, 2015 No. 266» ${ }^{14}$.

The Ministry of Health included in the Action Plan for the Implementation of the Concept on Development of the Public Health System in Ukraine the task of ensuring the development of the National Plan for the Development of Human Resources in the Public Health System, which will include the issues of education and training, mobility, career opportunities and development and approval of educational standards and educational programs, taking into account the best European and international experience in the specialty «Public Health» to provide three-level training (Bachelor's degree, Master's degree) and continuing professional development. In addition, the conceptual framework for the development of a model of public health education and training includes the task of shaping the future public health potential in line with changes and threats to public health at national and European levels, based on the best foreign education

${ }^{12}$ Pro zatverdzhennja pereliku ghaluzej znanj i specialjnostej, za jakymy zdijsnjujetjsja pidghotovka zdobuvachiv vyshhoji osvity, Postanova Kabinetu Ministriv Ukrajiny № 266 vid 29.04.2015 [On approval of the list of specialties for which higher education students are trained, Resolution of the Cabinet of Ministers of Ukraine № 266 of 29.04.2015]. Retrieved from: http://zakon4.rada.gov.ua/laws/ show/266-2015-п.

13 Pro zatverdzhennja standartu vyshhoji osvity za specialjnistju 229 «Ghromadsjke zdorov'ja» dlja drughogho (maghistersjkogho) rivnja osvity, Nakaz Ministerstva osvity i nauky Ukrajiny №1383 vid 12.12.2018 [On approval of the higher education standard in the specialty 229 «Public Health» for the second (Master's) degree of education, Order of the Ministry of Education and Science of Ukraine № 1383 of 12.12.2018]. Retrieved from: https://mon.gov.ua/ storage/app/media/vishcha-osvita/rekomendatsii-1648.pdf

${ }^{14}$ Pro vnesennja zmin do postanovy Kabinetu Ministriv Ukrajiny vid 29 kvitnja 2015 r. №266, Postanova Kabinetu Ministriv Ukrajiny №53 vid 01.02.2017 [On Amendments to the Resolution of the Cabinet of Ministers of Ukraine of April 29, 2015 No. 266, Resolution of the Cabinet of Ministers of Ukraine № 53 of 01.02.2017]. Retrieved from: https://zakon.rada.gov.ua/laws/show/53-2017-\%D0\%BF\#n2 
standards, researches and practice in the area of public health. The basis for the development of the above standard, plan and program were documents from WHO, WHO European Region, Association of Schools of Public Health in the European Region (ASPHER), Agency for Public Health Education Accreditation (APHEA), national strategy documents, best European experience.

The implementation of human resources policy should be aimed at various aspects: social - high level of development of human potential, meeting the expectations of the population for professional self-realization, decent pay; and economic - provision of all industries and sectors with qualified personnel, increasing the competitiveness of state, improving the level of welfare of the population.

The training of specialists in «Public Health» involves the formation of a new generation of professionals for public administration, local government, economic entities of various forms of ownership, including nongovernmental organizations in the field of public health. This would contribute to the improvement and implementation of the state policy aimed at solving the problems related to the worsening of medical-demographic situation in the country, inequality of access to health-saving and healthforming technologies and services, dissatisfaction of a considerable part of citizens with the state of medical care and protection of patients' rights, the necessity of development of cross-sectoral and inter-sectoral cooperation on public health in Ukraine in compliance with the national principle «health care in all state policies».

In particular, the training of specialists for educational degree of Bachelor is aimed at training specialists capable of solving complex tasks and problems in the field of public health or in learning process, which involves the application of certain theories and methods of the relevant science and is characterized by uncertainty of conditions and requirements.

The educational standard for the second educational degree (Master's degree) includes the objects of study, theoretical content of the subject area of study, methods and more. The objectives of Master's program are to acquire knowledge and skills in assessing health of the population and the determinants that influence it, as well as to develop and implement policies and measures aimed at preserving, promoting health and social well-being of the population.

The standard specifies that the training of specialists in Master's degree in the specialty 229 «Public Health» is carried out on the basis of the first (Bachelor's) and/or second (Master's) or equivalent level of higher education without limiting the specialty. 
At the same time, for the Master in specialty 229 «Public Health» on the basis of the first (Bachelor`s) level, the volume of educational-scientific (educational and professional) program constitutes 120 ECTS credits. A minimum of $35 \%$ of educational program scope should be aimed at acquisition of general and special (professional) competences in the specialty, defined by the Standard. It should be noted that competency formation was carried out taking into account the competences of public health professionals in the European Region ${ }^{15}$.

The integral competence of a Master in «Public Health» defines the ability to solve complex tasks and problems in public health or in learning process, which involves researches, application of scientific theories and analytical methods and is characterized by the complexity and uncertainty of the conditions.

In 2018, the first enrolment of students for Bachelor's degree and in 2019 - for Master`s degree was carried out in Ukraine.

In 2019, with a licensed amount of 550 students, 38 students were enrolled, including 5 under government order for budget funds. The Bachelor studies in «Public Health» are provided by the National University of Ostroh Academy and Sumy State University.

To prepare public health professionals under Master's program, with a licensed amount of 740 students, 52 students were admitted to higher education institutions, including 18 by government order. In Uzhhorod National University, 18 students have been admitted to the Master's program in the specialty «Public Health», 10 of them by government order. Masters in «Public Health» are trained by State Higher Educational Institution «Uzhhorod National University», I. Horbachevsky Ternopil State Medical University of the Ministry of Health of Ukraine, Kharkiv National Medical University, Municipal Higher Educational Institution «Zhytomyr Medical Institute» of Zhytomyr Regional Council.

Considering the largest number of students who are studying under Master's program in «Public Health» at Uzhhorod National University, we have researched and analysed the system of their preparation in this higher educational institution.

In accordance with the state standard for education under Master's program on a full-time basis the students were enrolled according to the

${ }^{15}$ Foldspengh A., Birt K., Otok R., (ed.). (2018). Perelik osnovnykh kompetencij fakhivciv ghromadsjkogho zdorov'ja Asociaciji uchbovykh zakladiv ghromadsjkogho zdorov'ja $v$ Jevropejsjkomu reghioni (ASPHER) [List of basic competences of public health professionals according to Association of Schools of Public Health in the European Region (ASPHER)]. Vol. 5. Brussels. 
principle of «cross-Master studies», having Bachelor's degree in the specialties «Human Health» and «Physical Culture and Sports». For studying under Master's program on a part-time basis the students were enrolled, having the first higher education in the specialty «Political Science» and «Medicine».

The positive aspect of preparation of Masters in the specialty «Public Health» at classical university, like Uzhhorod National University, is the presence of nonspecialized faculties and departments where professors can be involved in the preparation of Masters. An example of involving such specialists from other departments to formulate the competencies of future public health workers is given in Figure 1.

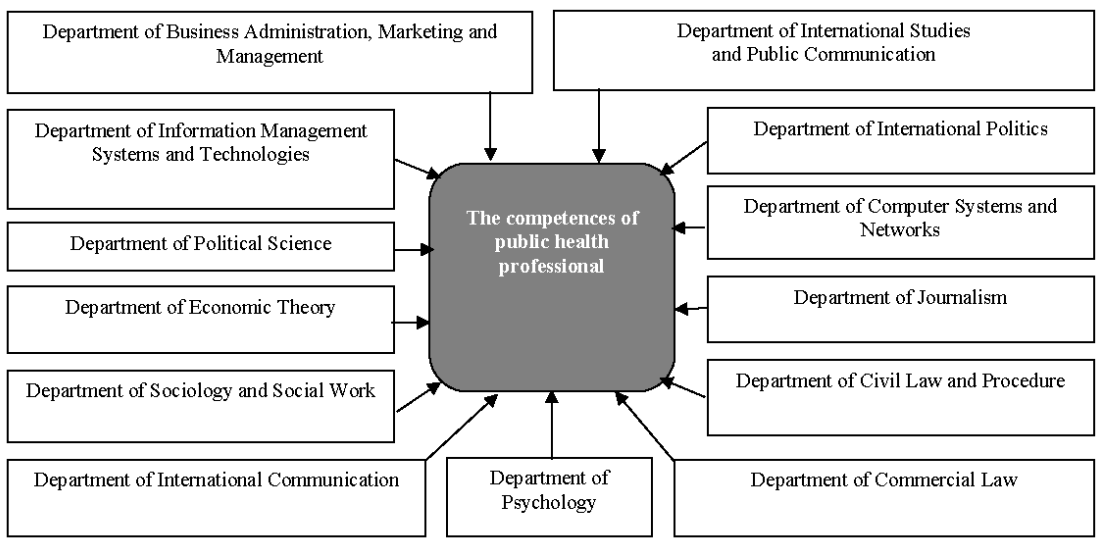

\section{Fig. 1. Departments professors of which can be involved in the preparation of Masters in «Public Health»}

\section{Analysis of training of public health professionals}

At Uzhhorod National University the educational and scientific program for Master's degree in the specialty 229 «Public Health» was developed in accordance with the requirements of the Law of Ukraine «On Higher Education» of 01.07.2014. № 1556-VII ${ }^{16}$. The Master's degree program in the specialty «Public Health» consists of 5 compulsory modules: introduction to public health, and public health system, policies, ethics,

16 Pro vyshhu osvitu, Zakon Ukrayiny №1556-VII vid 01.07.2014 [«About Higher Education», Law of Ukraine № 1556-VII of 01.07.2014]. Retrieved from: https://zakon.rada.gov.ua/laws/show/1556-18. 
management and leadership in the field of public health; epidemiology and biostatistics for public health professionals; monitoring and evaluation, data quality, data use and public health information; program planning, its implementation and evaluation; Business English; as well as 4 modules, one of which the Master chooses independently.

The Master's degree program is designed for 3600 hours (120 ECTS credits). The lecture course provides 462 academic hours. 512 academic hours were allocated for conducting seminars, 1318 academic hours - for practical classes, 1308 (36.3\%) academic hours - independent work. Independent work for preparation of Master's qualification work (thesis) includes 700 academic hours. Of the total number of academic hours, 30 hours are allocated to module control and 6 hours - to examinations ${ }^{17}$.

The structure of a discipline is shown in Figure 2.

\begin{tabular}{|c|c|c|c|c|c|}
\hline \multicolumn{4}{|c|}{ Classroom hours } & \multirow{2}{*}{$\begin{array}{c}\text { Independent } \\
\text { work }\end{array}$} & \multirow[b]{2}{*}{ Type of control } \\
\hline Total & Lectures & Seminars & $\begin{array}{c}\text { Practical } \\
\text { classes }\end{array}$ & & \\
\hline 3600 & 462 & 512 & 1318 & 1308 & $\begin{array}{l}\text { Oral questioning. } \\
\text { Solution of } \\
\text { situational } \\
\text { problems. } \\
\text { Module test } \\
\text { control. } \\
\text { Computer test. }\end{array}$ \\
\hline \multicolumn{5}{|c|}{ Total ECTS credits } & 90 \\
\hline \multicolumn{6}{|c|}{ including: } \\
\hline \multicolumn{5}{|c|}{ Scientific research work } & Type of control \\
\hline \multicolumn{2}{|c|}{ Credits } & 30 & \multicolumn{2}{|c|}{$\begin{array}{l}\text { Undertaking a scientific } \\
\text { independent research and } \\
\text { preparation of scientific } \\
\text { master's thesis }\end{array}$} & $\begin{array}{l}\text { Public defense of } \\
\text { scientific master's } \\
\text { thesis }\end{array}$ \\
\hline
\end{tabular}

\section{Fig. 2. The structure of the discipline «Public Health» at Uzhhorod National University}

Teaching methods include lectures and seminars, classes using remote method with the aid of Moodle system, practical classes on specific topics, including visits to practical public health facilities, preparation by masters of analytical reviews of scientific literature on specific topics, preparation of analytical materials describing medical-demographic situation in the region,

${ }^{17}$ Slabkyj Gh.O., Shafransjkyj V.V., Myronjuk I.S. (2017) Pytannja pidghotovky fakhivciv dlja sfery ghromadsjkogho zdorov'ja [Issues of Training Public Health Professionals]. Ukrajina. Zdorov’ja naciji. №3 (44), pp. 32-55. 
conducting business games, as well as independent implementation of research work, writing a scientific Master's thesis and its defence. In order to ensure that the necessary competences are acquired by the masters, the program is divided into disciplines. This division is presented in Fig. 3.

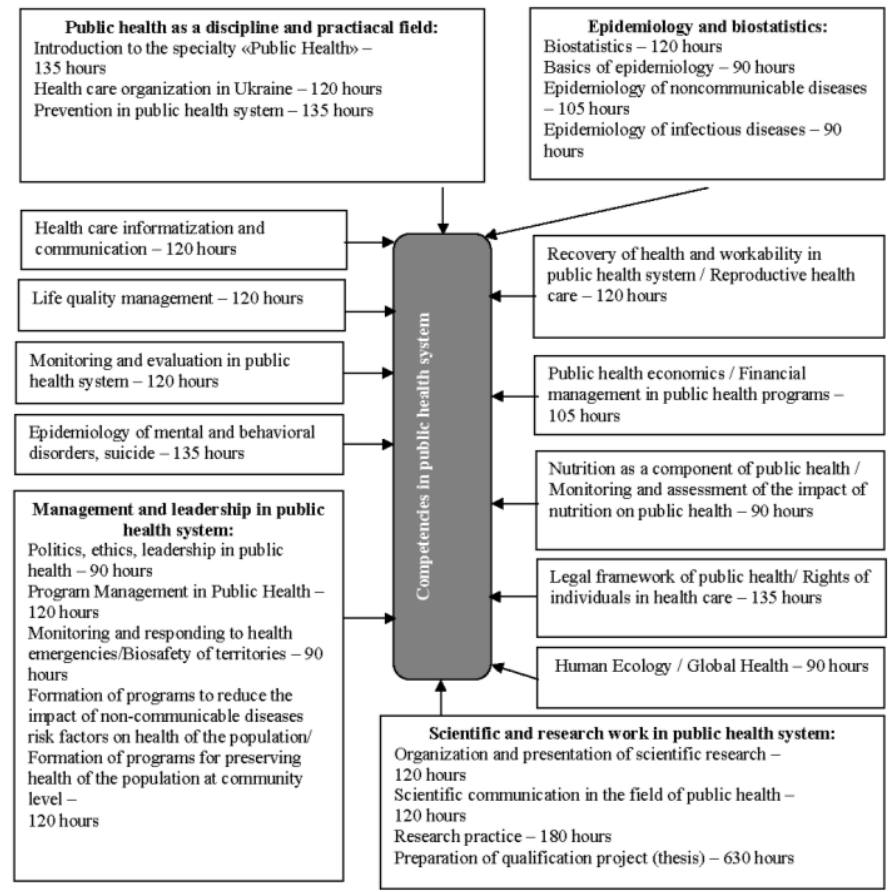

Fig. 3. Division of educational program into disciplines

The purpose of the Master's degree program in «Public Health» is to prepare specialists in this field for independent practical and scientific and pedagogical activity in accordance with certain competencies. The professional and scientific program provides for the formation of the ability to apply the acquired knowledge, abilities and skills on disciplines of general and professional training to solve typical tasks of the specialist's activity at relevant position or post, including conducting scientific-practical researches in the field of public health, teaching the subject «Public Health», conducting epidemiological surveillance of socially significant infectious and non-communicable diseases, the state of mental health of the population, 
environment; determination of environmental, socio-economic and medical determinants of health; organization and implementation of preventive and anti-epidemic measures; promoting healthy lifestyle and responsible attitude to a person's health; cross-sectoral cooperation for the sake of public health.

The program stipulates that working and educational practice, research work are carried out in accordance with the curriculum of Master's program in the specialty «Public Health» and are obligatory and present a type of educational activities directly oriented to professional and scientific training of students. Working and educational practice and research work consolidate the knowledge and skills acquired during mastering of theoretical disciplines and help students to develop practical skills and contribute to comprehensive formation of general and professional competences. In the course of learning Master's curriculum in the specialty «Public Health», students are expected to undergo working and educational practice and perform research work.

Practice bases are healthcare institutions, public health institutions, which have the necessary human and scientific and technical resources, the main activity of which has the object and types of professional activity of graduates in the specialty «Public Health».

The purpose of practice is acquisition by masters of experience and skills of collective and independent professional activity in the field of public health, including the assessment and monitoring of the state of health of the population, conducting research aimed at identifying factors that determine public health, the development of scientifically sound measures to preserve and promote health of the population, put them into practice and evaluate their effectiveness.

As a result of practice, the learner must acquire the following practical skills and competences: independent choosing and justification of the topic, purpose and objectives of the research, choosing and justification of the method and scope, which are adequate to the tasks; development of practical projects on pressing public health problems; mastering new theories, models, research methods, developing new methodological approaches and technologies; organization and participation in the assessment of the state of health of the population, epidemiological situation, the external environment; - planning and carrying out actions on health care and environmental protection, improvement of health of the population, organization of management in the field of public health; collecting and analysing public health information using modern methods of automated information collection and processing; processing and analysis of the obtained data with the help of modern information technologies; preparation 
and execution of scientific and technical projects and reports, normative and methodological documents.

Within the framework of the implementation of Master's curriculum in the specialty «Public Health», research work is also envisaged. Also preparation and defence of scientific master's project (thesis). The bases of the research work are departments, research institutions in this area of training and public health institutions with the necessary resources for the research.

The purpose of scientific and research work, performed by the masters, is to expand the acquired and new knowledge, test scientific hypotheses, establish patterns existing in nature, society, scientific generalization, scientific substantiation of projects.

A Master should know: the main directions and problems of research in public health area; structure of research, medical, preventive and public health institutions; organization of work of departmental and scientific units; computer operation safety rules; rules for collecting primary information; rules for processing and presentation of research results.

A Master should be able to: work with scientific literature on the chosen problem; set tasks, select adequate research methods and determine the size of sample amount of a research; analyse the data obtained from scientific research; make adjustments to research design; formulate conclusions and practical recommendations on the results of scientific research; to formulate the basic provisions of scientific qualification works: relevance, purpose, tasks, object, subject, methods of research, novelty, basic statements that are brought to the defence, theoretical and practical importance of a thesis.

A Master should have: skills of searching and generalization of sources of scientific literature; technology of planning and execution of research work at its various stages.

With a view to preparing masters at the University since September 1, 2019, the Department of Health Sciences was opened and its staffing list and personnel was formed.

The department has among its employees a doctor, $\mathrm{PhDs}$ and specialists with extensive practical experience related to the provision of services that are characteristic of public health system, including specialists in the organization and management of health care, epidemiology, monitoring and evaluation, sociology, social work and practical psychology, information technology and communication.

Having a considerable potential, during the preparation of masters, the teaching staff of the department faces a number of problems. The most important of these are: 
- lack of modern national educational and methodological developments for conducting classes on the topics defined by the program;

- lack of a state system of assessment of knowledge acquired by students during their studies under Master's program;

- the lack of masters who were enrolled to study in Master`s program on the principle of "cross-Master studies», the necessary basic knowledge to master certain subjects, such as «Epidemiology».

An important problem for both students and teachers is that the public health system is just being created. In some regions, including Transcarpathian region, Public Health Centers are not established and students are not able to anticipate their first place of work, and accordingly their specialization and list of priority competencies.

These problems are the subject to solution at all levels of management from the central (Ministry of Health of Ukraine and Ministry of Education and Science of Ukraine) to the basic level of higher education institutions and united communities.

\section{CONCLUSIONS}

In order to implement «European Action Plan for Strengthening of Public Health Capacities and Services», a public health system is being created in Ukraine, which needs qualified personnel. The Cabinet of Ministers of Ukraine approved the specialty «Public Health» and the Ministry of Education and Science of Ukraine approved national educational standards for training students for Bachelor's and Master's degrees. The licensed number of trained specialists in the amount of annual admission of students for preparation of Bachelor's degree - 550 persons and Master's degree -740 persons was also approved.

The enrolment of students in 2019 for mastering specialty «Public Health» (Bachelor's degree 6.9\% of the licensed number, Master's degree $7.0 \%$ of the licensed number) indicates that this specialty is not favourable one among entrants. The low demand for specialty «Public Health» is due to the lack of information on post-graduation employment. Training of future specialists is carried out in accordance with the requirements of the Law of Ukraine «On Higher Education» of 01.07.2014, № 1556-VII and in accordance with the state standard.

The educational program for obtaining Master's degree in the specialty «Public Health» consists of 5 compulsory modules: introduction to public health, and public health system, policies, ethics, management and leadership in the field of public health; epidemiology and biostatistics for public health professionals; monitoring and evaluation, data quality, data use 
and public health information; program planning, its implementation and evaluation; Business English; as well as 4 modules, one of which master chooses independently.

The educational program for obtaining Master's degree is designed for 3600 hours (120 ECTS credits). The lecture course provides 462 academic hours.

512 academic hours were allocated for conducting seminars, 1318 academic hours - for practical classes, 1308 (36.3\%) academic hours independent work. Independent work for preparation of Master's qualification work (thesis) includes 700 academic hours. Of the total number of academic hours, 30 hours are allocated to module control and 6 hours - to examinations.

The problems in organization of the educational process are the lack of modern national educational and methodological developments for conducting classes on the topics defined by the program, the state system of knowledge assessment acquired by students during their Master studies, and the lack by Masters enrolled on the basis of principle of «cross-Master studies», the necessary basic knowledge to master certain subjects.

Existing problems need to be addressed at all levels of management, from central to basic - united communities and higher education institutions.

\section{SUMMARY}

Ukraine experiences the formation of a public health system based on international approaches. In order to ensure its effective functioning in the country, the specialty «Public Health» was approved and training of specialists of the first educational level - Bachelor's degree and the second educational level - Master's degree began. State educational standards for the training of specialists in the field of public health system have been approved. Licensed number for training of specialists have also been approved. The enrolment of students in 2019 for mastering specialty «Public Health» (Bachelor's degree 6.9\% of the licensed number, Master's degree $7.0 \%$ of the licensed number) indicates that this specialty is not favourable one among entrants. The low demand for specialty «Public Health» is due to the lack of information on post-graduation employment.

Training of future specialists is carried out in accordance with the state standard, but there is no modern educational and methodological support in educational institutions. 


\section{REFERENCES}

1. Zdorov'e - 2020. Osnovy evropeyskoy politiki i strategiya dlya XXI veka (2013) [Health - 2020. European policy framework and strategy for the 21st century]. Retrieved from: http://www.euro.who.int/ PubRequest?language $=$ Russian.

2. Acheson D. (1988) Public health in England: the report of the Committee of Inquiry into the Future Development of the Public Health Function. London, H. M. Stationery Office.

3. Evropeyskiy plan deystviy po ukrepleniyu potentsiala i uslug obshchestvennogo zdravookhraneniya (2012) [European Action Plan for Strengthening of Public Health Capacities and Services]. Copenhagen: WHO Regional Office for Europe, (document EUR/RC62/12).

4. Slabkyj Gh.O., Myronjuk I.S., Kachala L.O. (2017) Systema ghromadsjkogho zdorov'ja: bachennja Vsesvitnjoji orghanizaciji okhorony zdorov'ja, Osnovni operatyvni funkciji ghromadsjkogho zdorov'ja ta jikh zmist [Public Health System: World Health Organization Vision, Essential Public Health Functions and Their Meaning]. Ukrajina. Zdorov'ja naciji, no. 3 (44), pp. 24-31.

5. Sistemy zdravookhraneniya - zdorov'e - blagosostoyanie: Evropeyskaya ministerskaya konferentsiya VOZ po sistemam zdravookhraneniya (2008) [Health systems - Health - Welfare: WHO European Ministerial Conference on Health Systems]. Tallinn, Estonia. Report (2009) Copenhagen: WHO Regional Office for Europe. Retrieved from: http://www.euro.who.intassets/pdf_file/0003/78951/E92150 R.pdf.

6. Komissiya po sotsial'nym determinantam zdorov'ya. Likvidirovat' razryv $\mathrm{v}$ techenie zhizni odnogo pokoleniya. Soblyudenie printsipa spravedlivosti $\mathrm{v}$ zdravookhranenii putem vozdeystviya na sotsial'nye determinanty zdorov'ya (2009) [Commission on Social Determinants of Health. Closing the gap in a generation. Health equity through action on the social determinants of health]. Final report of the Commission on the Social Determinants of Health. Geneva, WHO. Retrieved from: http://www.who.int/ social_determinants/thecommissionfnalreport/ru/index.html.

7. Rezolyutsiya WHA62.14 Vsemirnoy assamblei zdravookhraneniya “Umen'shenie nespravedlivosti $\mathrm{v}$ otnoshenii zdorov'ya posredstvom vozdeystviya na sotsial'nye determinanty zdorov'ya" (2009) [Resolution WHA62.14 of World Health Assembly «Reducing health inequities through action on the social determinants of health»]. Geneva, WHO. Retrieved from: http://apps.who.int/gb/or/r/r_wha62r1.html.

8. Pro Strateghiju stalogho rozvytku «Ukrajina - 2020», Ukaz Prezydenta Ukrajiny № 5/2015 vid 12.01.2015 [On the Sustainable 
Development Strategy «Ukraine 2020», Presidential Decree № 5/2015 of 12.01.2015]. Retrieved from: https://zakon.rada.gov.ua/laws/ show/5/2015

9. Ughoda pro asociaciju mizh Ukrajinoju ta JeS: zmist ta implementacija [EU-Ukraine Association Agreement: content and implementation.]. Retrieved from: https://parlament.org.ua/upload/ docs/final_1.pdf

10. Pro skhvalennja Koncepciji rozvytku systemy ghromadsjkogho zdorov'ja, Rozporjadzhennja Kabinetu Ministriv Ukrajiny № 1002-r. vid 30.11.2016 [On approval of the Concept of development of the public health system, Order of the Cabinet of Ministers of Ukraine №1002-p. of 30.11.2016]. Retrieved from: https://zakon.rada.gov.ua/laws/show/10022016-\%D1\%80

11. Pro zatverdzhennja planu zakhodiv shhodo realizaciji Koncepciji rozvytku systemy ghromadsjkogho zdorov'ja, Rozporjadzhennja Kabinetu Ministriv Ukrajiny № 560-r vid 18.08.2017 [On Approval of the Action Plan for the Implementation of the Concept of Public Health System Development, Order of the Cabinet of Ministers of Ukraine № 560-p of 18 August 2017]. Retrieved from: https://zakon.rada.gov.ua/laws/show/5602017-\%D1\%80

12. Pro zatverdzhennja pereliku ghaluzej znanj i specialjnostej, za jakymy zdijsnjujetjsja pidghotovka zdobuvachiv vyshhoji osvity, Postanova Kabinetu Ministriv Ukrajiny № 266 vid 29.04.2015 [On approval of the list of specialties for which higher education students are trained, Resolution of the Cabinet of Ministers of Ukraine № 266 of 29.04.2015]. Retrieved from: http://zakon4.rada.gov.ua/laws/ show/266-2015-п.

13. Pro zatverdzhennja standartu vyshhoji osvity za specialjnistju 229 «Ghromadsjke zdorov'ja» dlja drughogho (maghistersjkogho) rivnja osvity, Nakaz Ministerstva osvity i nauky Ukrajiny №1383 vid 12.12.2018 [On approval of the higher education standard in the specialty 229 «Public Health» for the second (Master's) degree of education, Order of the Ministry of Education and Science of Ukraine № 1383 of 12.12.2018]. Retrieved from: https://mon.gov.ua/ storage/app/media/vishcha-osvita/rekomendatsii1648.pdf

14. Pro vnesennja zmin do postanovy Kabinetu Ministriv Ukrajiny vid 29 kvitnja 2015 r. № 266, Postanova Kabinetu Ministriv Ukrajiny № 53 vid 01.02.2017 [On Amendments to the Resolution of the Cabinet of Ministers of Ukraine of April 29, 2015 No. 266, Resolution of the Cabinet of Ministers of Ukraine № 53 of 01.02.2017]. Retrieved from: https://zakon.rada.gov.ua/laws/show/53-2017-\%D0\%BF\#n2 
15. Foldspengh A., Birt K., Otok R., (ed.). (2018). Perelik osnovnykh kompetencij fakhivciv ghromadsjkogho zdorov'ja Asociaciji uchbovykh zakladiv ghromadsjkogho zdorov'ja v Jevropejsjkomu reghioni (ASPHER) [List of basic competences of public health professionals according to Association of Schools of Public Health in the European Region (ASPHER)]. Vol. 5. Brussels.

16. Pro vyshhu osvitu, Zakon Ukrayiny №1556-VII vid 01.07.2014 [«About Higher Education», Law of Ukraine № 1556-VII of 01.07.2014]. Retrieved from: https://zakon.rada.gov.ua/laws/show/1556-18.

17. Slabkyj Gh.O., Shafransjkyj V.V., Myronjuk I.S. (2017) Pytannja pidghotovky fakhivciv dlja sfery ghromadsjkogho zdorov'ja [Issues of Training Public Health Professionals]. Ukrajina. Zdorov'ja naciji. № 3 (44), pp. 32-55.

\section{Information about the author:}

Bilak-Lukianchuk V. Yo., orcid.org/0000-0003-3020-316X Associate Professor at the Department of Health Sciences,

Uzhhorod National University 29, Mytna str., 88000, Uzhhorod, Ukraine 